\title{
Characterization and Pathogenicity of Fusarium oxysporum as the Causal Agent of Fusarium Wilt in Chili (Capsicum annuum L.)
}

\author{
REJEKI SITI FERNIAH ${ }^{1 *}$, BUDI SETIADI DARYONO ${ }^{2}$, RINA SRI KASIAMDARI ${ }^{2}$, \\ AND ACHMADI PRIYATMOJO ${ }^{3}$
}

\author{
${ }^{I}$ Department of Biology, Diponegoro University, \\ Jl. Prof. Sudharto SH Tembalang Semarang, Indonesia; \\ ${ }^{2}$ Faculty of Biology, Gadjah Mada University, Jl Teknika Selatan Sekip Utara Yogyakarta Indonesia; \\ ${ }^{3}$ Faculty of Agriculture, Gadjah Mada University, Sekip Unit 1 Yogyakarta, Indonesia;
}

\begin{abstract}
Fusarium wilt is a serious disease attacking chili plants in Central Java which cause lost of chili productivity. Fusarium wilt is caused by pathogenic fungi Fusarium oxysporum, which is host specific. The objectives of this research were to characterize the pathogenic $F$. oxysporum as the causal agent of fusarium wilt in chili plants and to observe the virulence of the pathogen. Fungal pathogen was isolated from Tawangmangu as an endemic area of fusarium wilt in Central Java. The fungi was characterized morphologically and identified molecularly by its internal transcribed spacer regions (ITS regions). Pathogenicity test was done to observe the virulence of the pathogen. One pathogenic strain was isolated from Tawangmangu, Karanganyar and was identified morphologically and molecularly as F. oxysporum.
\end{abstract}

Key words: Characterization, pathogenicity, Fusarium oxysporum, Capsicum annuum

Layu fusarium merupakan salah satu penyakit tanaman yang sering dikeluhkan oleh para petani cabai di Jawa Tengah karena dapat menyebabkan gagal panen. Penyakit tersebut disebabkan oleh jamur Fusarium oxysporum yang bersifat spesifik inang. Penelitian ini bertujuan untuk menentukan karakter morfologis dan identifikasi secara molekular F. oxysporum patogen tanaman cabai dan mengetahui virulensi patogen tersebut. Patogen diisolasi dari Tawangmangu sebagai daerah endemis layu fusarium di Jawa Tengah. Jamur pathogen dikarakterisasi secara morfologis dan diidentifikasi secara molekular menggunakan gen ITS. Isolat $F$. oxysporum yang didapat diuji patogenitasnya pada tanaman cabai. Hasil penelitian mendapatkan satu isolat jamur yang bersifat pathogen serta secara morfologis dan molekular adalah jamur F. oxysporum.

Kata kunci : Karakterisasi, patogenitas, Fusarium oxysporum, Capsicum annuum

Chili is a potential horticulture in Indonesia and produced mainly in Java. Indonesia produced 954.360 ton red chili in year 2012 and $48 \%$ of the plantation was located in Java (Anonim 2013). Central Java has the second biggest of chili plantation but many plants have been attacked by fusarium wilt especially in the rainy seasons. The symptoms of fusarium wilt are wilting, vein clearing in younger leaflets, epinasty, stunting and yellowing of older leaves (Agrios 2005). According to Agrios (2005), fusarium wilt in plants was usually caused by Fusarium oxysporum. This species can infects more than 100 species of plants and causes the wilt symptoms. Fusarium oxysporum was the main disease in Thailand chili crops and one of the causal agents of wilting chili in India, China, and Indonesia (Ali 2006).

Pathogenicity of $F$. oxysporum in many plants have been studied for many decades. It is because the pathogen has a systemic reaction in plants that causes

*Corresponding author; Phone: +62-24-76480923, ferniah_mikro@yahoo.com the death of the infected plants. Fusarium oxysporum as the causal agent of wilting banana was reported by Groenewald (2005). Genetic diversity and pathogenicity of $F$. oxysporum was studied in Japanese onion (Dissanayake et al. 2009) and in Indonesian onion (Choiruddin 2010). Pathogenic F. oxysporum f. $\mathrm{sp}$ vasinfectum was determined in cotton roots by PCR based (Abd-Elsalam et al. 2006). The fusarium wilt had also been observed in melon (Herman and Perl-Treves 2007; Oumouloud et al. 2008). In Solanaceae, F. oxysporum was reported as the causal agent in tomato (Hibar et al. 2007; Jacobs et al. 2013), potato (Bayona et al. 2011; Du et al. 2012), and eggplant (Altinok et al. 2014). Studies of fusarium wilt in chili were done morphologically (Zahara and Harahap 2007), biologically (Nugraheni 2010), and enzymatically (Chaiyawat et al. 2008; Wongpia and Lomthaisong 2010).

Many chili crops in Indonesia have problems by fusarium wilt but the causal agent have not been determined yet. In this research a pathogen causing the 
fusarium wilt in chili was isolated and identified morphologically and molecularly. Molecular identification confirmed the morphological character. In this study, isolation of the pathogen was done from the endemic area of fusarium wilt in Tawangmangu, Karanganyar, Central Java.

\section{MATERIALS AND METHODS}

Plant Materials. Wilting plant materials were collected from chili plantation in Tawangmangu Karanganyar. Treaty plants were TM999 cultivar (seeds produced by Seminis, Monsanto, Korea) and Gantari cultivar (seeds produced by Balai Penelitian dan Pengembangan Hortikultura Ngipiksari, Yogyakarta, Indonesia) grown in sterile soil.

Fungal Isolation and Identification. Fungi were isolated from the browning vascular of plants. The stem was cut on the border of brown vascular and healthy vascular. A five millimeter slice of the stems were surface sterilized in $70 \%$ ethanol for one minute, rinsed in sterile water and dried with tissue, and grown on the Potato Dextrose Agar (PDA). The cultures were incubated at $25^{\circ} \mathrm{C}$ with $12 \mathrm{~h}$ dark and $12 \mathrm{~h}$ light cycle for 2 days. Each colony was transferred into new PDA and incubated for 5 days to get pure culture of isolate. Characterization was done based on the morphology of colonies and cells. When Fusarium species is present, the isolate was grown on Synthetic Nutrient-Poor Agar (SNA) to analyse the shape of macroconidia and microconidia. Identification was done by comparing the morphology with the atlas of Fusarium (Leslie and Summerell 2006; and Samson et al. 2008). A single spore of Fusarium oxysporum was used for further test (as master isolate).

Pathogenicity Test. The $F$. oxysporum was grown in Potato Dextrose Broth (PDB) for 4 days. Conidia densities were calculated with haemacytometer and adjusted to $10^{6}$ conidia/mL. The inoculum was inoculated in chili plant by root dip method (Herman and Perl-Treves 2007; Karimi et al. 2010). One month old of healthy chili plants were taken from the soil. The root were rinsed in water, soaked in $1 \%$ Chlorox for 1 minute, rinsed with sterile water, and then soaked in fungal suspension for 30 minutes. This treatment were done for 10 plants. Roots of healthy plant were soaked in sterile water was done as control. Each plant was planted in sterile soil in polybags. Disease symptoms were observed every odd days after inoculation (DAI). Symptoms were remarked by the stunting, chlorosis, and/or wilting of the leaves which determined by scoring. Score $0=$ no symptom, $1=$ lower height compared to control, $2=$ lower height and chlorosis, $3=10 \%$ chlorosis and/or $10 \%$ wilting, $4=11-25 \%$ wilting, $5=2650 \%$ wilting, $6=51 \quad 100 \%$ wilting and dead.The Disease Severity Index (DSI) was determined according to Wongpia \& Lomthaisong, 2010:

$\mathrm{DSI}=$

$\sum \frac{\text { (disease severity scale } \mathrm{x} \text { number of plants in each }}{\text { scale) }}$

The highest numerical scale index $\mathrm{x}$ total number of plants

Pathogen was re-isolated from the symptomatic plant. The pathogen was compared morphologically and molecularly with the master isolate.

Molecular Identification. Master isolate and isolate from symptomatic plant were identified molecularly. Molecular identification of fungi was done using ITS regions (Abd-Elsalam et al. 2006; Toju et al. 2012). The ITS rDNA of the isolate was amplified by Polymerase Chain Reaction (PCR). Pair of primers used were ITS1 and ITS4. Sequences of the primers were forward ITS1: 5'-TCCGTAGGTGAACCTGCG G-3' and reverse ITS4: 5' - TCCTCCGCTTATTGATA TGC-3', with target size $540-570$ bp. PCR was done with KAPA2G Fast PCR Kit. PCR program for ITS rDNA was $95^{\circ} \mathrm{C} 3$ minutes for pre-denaturation, $95^{\circ} \mathrm{C}$ 10 second for denaturation, $52{ }^{\circ} \mathrm{C} 10$ second for annealing, and $72{ }^{\circ} \mathrm{C} 10$ second for polimeration. The cycle was repeated 39 times, and the final extention was $72^{\circ} \mathrm{C} 5$ minutes. PCR products were verified in $2 \%$ agarose gel electrophoresis and the DNA was sequenced. The sequencing product was analysed by BlastN in the GeneBank database using MEGA 5.1 software.

\section{RESULTS}

Tawangmangu was endemic of fusarium wilt in the rainy season 2013. There were wilting leaves and browning or discoloration in the stem of the diseased plants caused by fusarium wilt. One strain of Fusarium oxysporum, which was then called P1a, was successfully isolated from the diseased plants in Tawangmangu.

A specific fungi was successfully isolated from the stems. Figure 1 showed the morphological characters of the fungi. The observed morphological characters were as follows: colony with white cottony aerial 
mycellium and purple on the reverse with $4-5 \mathrm{~cm}$ diameter at 5 days incubation on PDA. Conidia was grown from short phialid with a false head. Macroconida was straight fussiform, pedicellate basal cell, 27 - 46 x 3 - 4,5 $\mu \mathrm{m}$, with 3 - 5 septates. Microconidia were abundant, ellipsoid or fussiform without or with $1-2$ septates, 5 - 15 x 2,2 - 3,5 $\mu \mathrm{m}$. Chlamydospore was formed terminally or intercallary, single or in pairs. The morphology has previously been described by Leslie and Summerell (2006), and Samson et al. (2008), as the characteristics $F$. Oxysporum, thus confirming the identification of the isolate.

The pathogenicity test showed that P1a caused wilting in chili. Figure 2 showed that the symptom increased significantly 15 DAI. At 19 DAI, the fungi caused wilting of TM999 cultivar and Gantari cultivar with DSI scores 0.4 and 0.63 , respectively. So the P1a isolate was pathogenic to both cultivars. Re-isolation from the symptomatic chili plants obtained one isolate that is morphologically similar to P1a isolate. The isolate was named P1a'. Both isolates were identified molecularly.
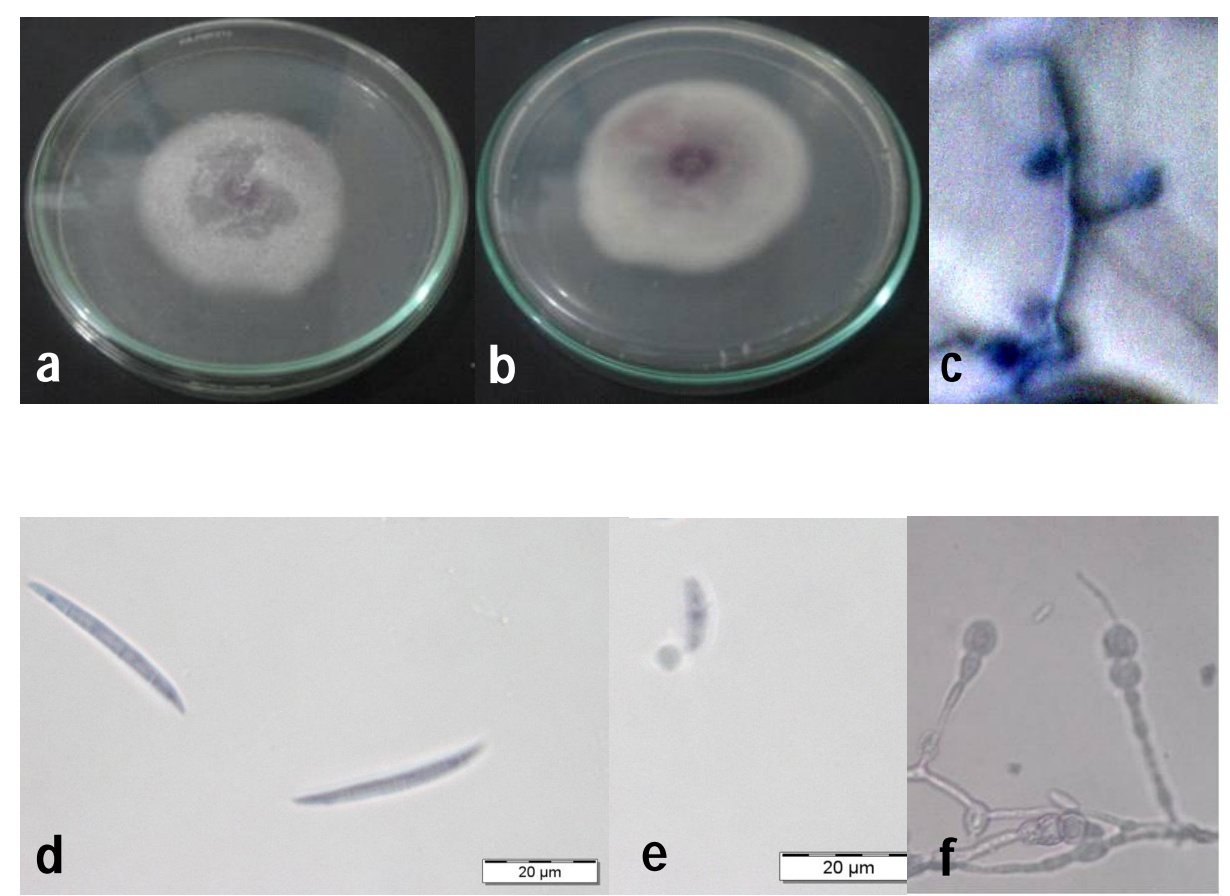

Fig 1 Morphology of Fusarium oxysporum. a. Colony, b. Reverse colony, c. Phialid, d. Macroconidia, e. Microconidia, f. Chlamydospore.

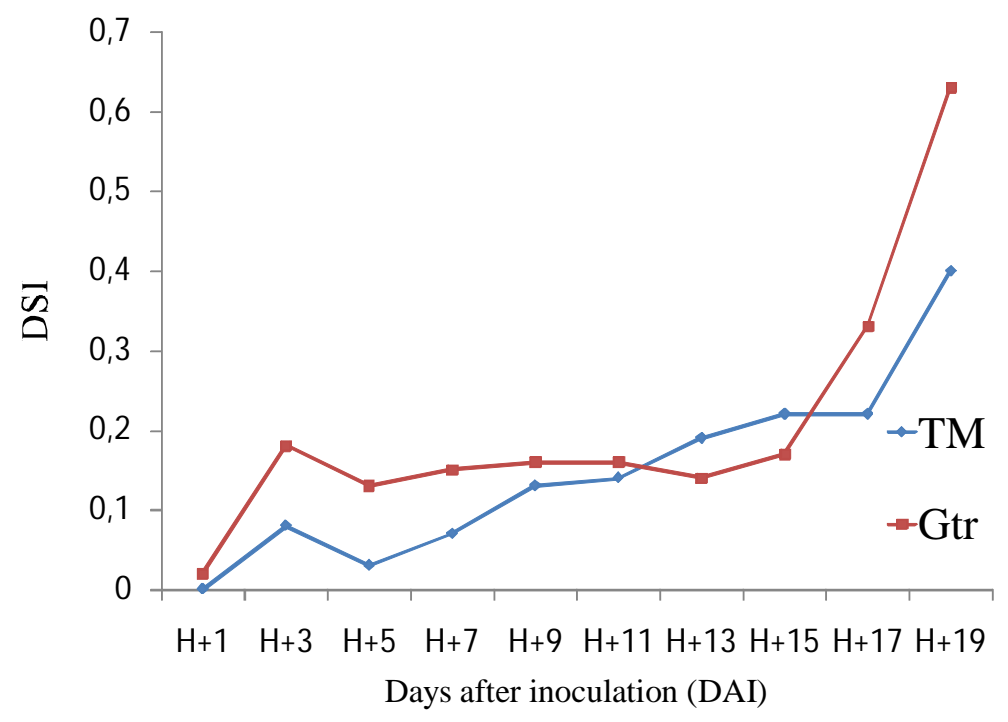

Fig 2 Disease severity index of the chili plants by F. oxysporum. TM : TM999 cultivar, Gtr : Gantari cultivar. 


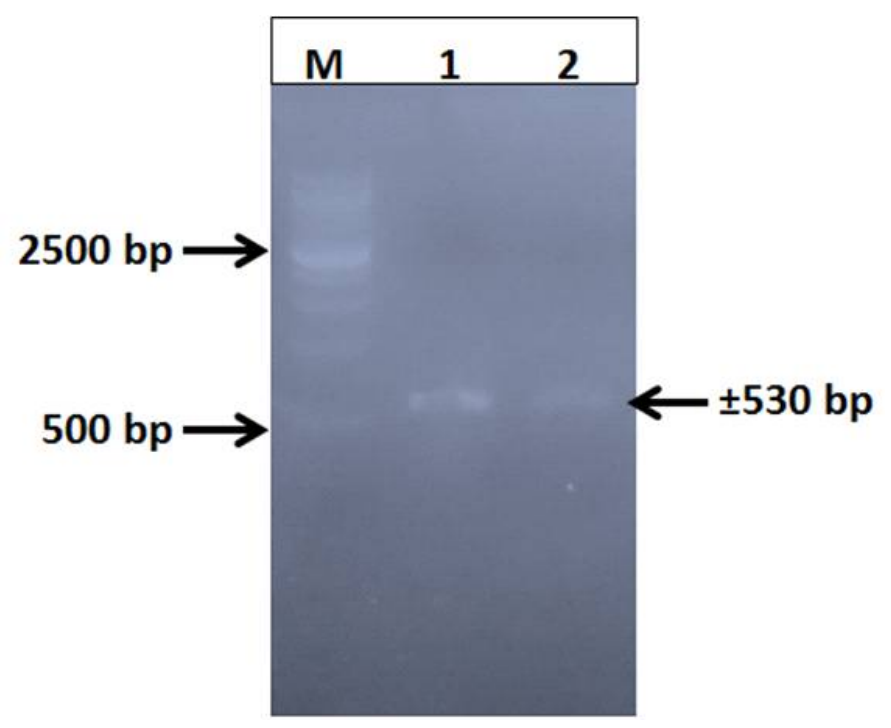

Fig 3 PCR products of F. oxysporum's ITS rDNA. P1a (lane 1) and P1a' (lane 2) as 530 bp. M is DNA marker ladder (Geneaid).

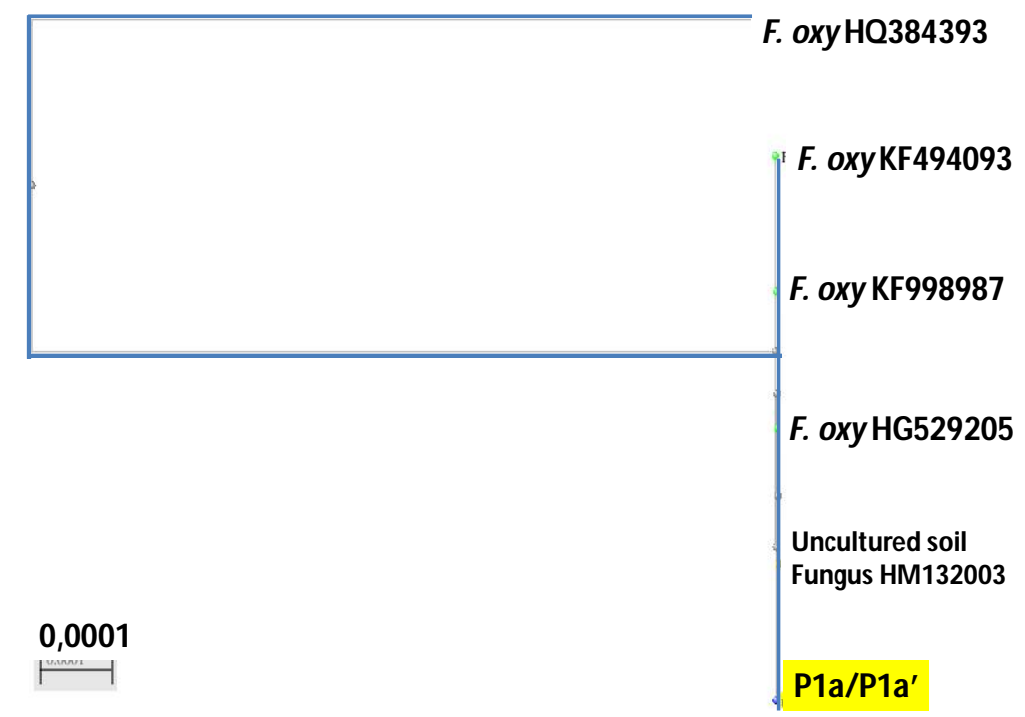

Fig 4 Phylogenetic tree of $F$. oxysporum pathogenic in chili (yellow box was P1a/P1a').

Molecular analysis showed similarity in the DNA sequences of P1a and P1a'. Figure 3 showed the PCR products of of P1a and P1a' rDNA. The alignment of these sequences showed $100 \%$ similarity to Fusarium oxysporum accession number KF998987.1. Figure 4 showed the phylogenetic tree of the sequences with $F$. oxysporum rDNA sequences obtained from the GeneBank database.

\section{DISCUSSION}

Fusarium wilt in Tawangmangu chili plantation covered $3040 \%$ area and caused loss of crops. The pathogen attacked plants in young and mature plants. Symptoms in young plants were stunting, chlorosis, wilting, and finally death. If the pathogen attacked a mature plant, flowers and fruits of the plant not develop normally. The disease was named fusarium wilt because wilting is the common observable symptoms. Wilting is actually a secondary symptom. The primary symptom was browning or discoloration in the basal stem, that is only observable by cutting the stem.

Macroscopical and microscopical characterization confirmed that the isolate was $F$. oxysporum. Molecular identification was needed to proof the name of the species. The rDNA ITS regions showed that P1a was the same as $\mathrm{P} 1 \mathrm{a}$, and confirmed the identity as $F$. 
oxysporum KF998987.1. The rDNA ITS is a region commonly used in the fungal molecular characterization and taxonomic classification. However, it cannot be used in taxonomic classification below the species level, since will require more selective/specific sequences as well as specific primers for the sequence amplification, for example a pair of unique primer developed by Abd-Elsalam et al. (2006), which is specific to the sequence of Fusarium oxysporum f.sp vasinfectum.

Pathogenicity test showed that the $F$. oxysporum from diseased chili was a pathogenic fungi and caused the same symptoms in chili plants. The fungi cause stunting and wilting with or without yellowing. The wilting started from the older leaves and spread to the younger. The stem of the plants had vascular discoloration or browning in the transverse cutting. The wilting increased 15 DAI, when the pathogen had successfully infected the chili plants. The pathogen needed time to enter the plant root through wounding and therefore penetrated and colonized the vascular. Pathogen colonization in vascular bundle inhibited water and nutrient transport from soil to the shoot (Agrios 2005) so it caused wilting of the leaves. The time required for the $F$. oxysporum infection was similar to pathogenesis test in chili seedling (Suryanto et al. 2010) and wilted rocket plant (Srinivasan et al. 2011). The fungi needed 13 - 17 DAI to infect a plant and show symptoms. Due to its capability to grow on the nutrient medium, the $F$. oxysporum is classified as a non-obligate pathogen. The pathogen can grow and multiply on dead organic matter as saprophytic microorganism. In the case of Fusarium, they live in soil as chlamydospores. The chlamydospores were dormant in the soil until they met a specific host to grow. Planting the soil with soybean may not endangere the plants, but planting with chili will wake up the pathogen. So plants rotation is needed in the field to inactivate the pathogen.

\section{ACKNOWLEDGEMENT}

This research is a part of dissertation report funded by the BPPS Program, Ministry of Education Republic of Indonesia, year 2011 - 2014.

\section{REFERENCES}

Abd-Elsalam KA, Asran-Amal A, Schnieder F, Migheli Q, Verreet J-A. 2006. Molecular detection of Fusarium oxysporum f. sp. vasinfectum in cotton roots by PCR and real-time PCR assay. Journal of Plant Diseases and Protection 113: 14 - 19.

Agrios GN. 2005. Plant Pathology. $5^{\text {th }}$ edition. Elsevier Academic Press. London.

Ali M. (ed.). 2006. Chili (Capsicum spp.) Food Chain Analysis: Setting Research Priorities in Asia. Shanhua, Taiwan: AVRDC - The World Vegetable Center, Technical Bulletin No. 38, AVRDC Publication 06-678. P157 - 206.

Altinok HH, Can C, Boyaci HF, Topcu V. 2014. Genetic variability among breeding lines and cultivars of eggplant against Fusarium oxysporum f. sp. melongenae from Turkey. Phytoparasitica 42: 75 - 84.

Anonim. 2013. Produksi Cabai Besar, Cabai Rawit, dan Bawang Merah Tahun 2012. Berita Resmi Statistik Badan Pusat Statistik No. 54/08/ Th. XVI, 1 Agustus 2013.

Bayona LG, Grajales A, Cardenas, ME, Sierra R, Garcia MCC, Bernal A, Jimenez P, Restrepo S. 2011. First Report of Fusarium oxysporum Causing Potato Dry Rot in Solanum tuberosum in Colombia. New Disease Reports 24: 14.

Chaiyawat P, Boonchitsirikul C, Lomthaisong KS. 2008. An investigation of a defensive chitinase against Fusarium oxysporum in pepper leaf tissue, $\mathrm{Mj}$. Int. J. Sci. Tech. $2: 150-158$.

Choiruddin MF. 2010. Virulensi dan Keanekaragaman Genetika Fusarium oxysporum f.sp cepae Penyebab Busuk Pangkal pada Bawang Putih. Skripsi. Universitas Sebelas Maret Surakarta.

Dissanayake MLMC, Kashima R, Tanaka S, Ito S. 2009. Genetic Diversity and Pathogenicity of Fusarium oxysporum Isolated from Wilted Welsh Onion in Japan. J Gen Plant Pathol 75: 125 - 130. doi 10.1007/s10327009-0152-6.

Du M, Ren X, Sun Q, Wang Y, Zhang R. 2012. Characterization of Fusarium spp. Causing Potato Dry Rot in China and Susceptibility Evaluation of Chinese Potato Germplasm to the Pathogen. Potato Research $55: 175$ \& 184.

Groenewald S. 2005. Biology, Pathogenicity and Diversity of Fusarium oxysporum f.sp cubense. Thesis. University of Pretoria. Pretoria.

Herman R, Perl-Treves R, 2007, Characterization and Inheritance of a New Source of Resistance to Fusarium oxysporum f. sp. melonis Race 1.2 in Cucumis melo. Plant Disease 91: 1180 1186. doi 10.1094/PDIS-91-91180.

Hibar K., Daami-Remadi M, El Mahjoub M. 2007. Induction of resistance in tomato plants against Fusarium oxysporum f. sp. radicis-lycopersici by Trichoderma spp. Tunisian Journal of Plant Protection 2: 47-58. 
Jacobs A, Govender R, Heerden SW. 2013. Fusarium oxysporum f. sp. lycopersici race 3 causing tomato wilt in South Africa. Australasian Plant Dis. 8:145-147.

Karimi R, Owuoche JO, Silim SN, 2010, Inheritance of fusarium wilt resistance in pigeonpea [Cajanus cajan (L.) Millspaugh]. Indian J. Genet. 70(3).

Leslie JF, BA Summerell. 2006. The Fusarium Laboratory Manual. Blackwell Publishing. Iowa.

Nugraheni ES. 2010. Karakterisasi Biologi Isolat-Isolat Fusarium sp pada Tanaman Cabai Merah (Capsicum annuиm L.) Asal Boyolali. Skripsi. Universitas Sebelas Maret Surakarta.

Oumouloud A, Torres RG, Andrés MSA, Alvarez JM. 2008. A new gene controlling resistance to Fusarium oxysporum f.sp. melonis races 0 and 2 in melon. Proceedings of the IXth UCARPIA meeting on genetics and breeding of Cucurbitaceae (Pitrat M, ed), INRA, Avignon (France), May 21-24th, 2008.

Samson RA, J Houbraken U Thrane JC Frisvad B Andersen. 2008. Food and Indoor Fungi. CBS-KNAW Fungal Biodiversity Centre Utrecht. Netherlands.
Srinivasan K, Spadaro D, Poli A, Gilardi G, Gullino ML, Garibaldi A. 2011. Genetic Diversity and Pathogenicity of Fusarium oxysporum Isolated from Wilted Rocket Plants in Italy. Phytoparasitica DOI 10.1007/s12600011-0207-z.

Suryanto D, Patonah S, Munir E. 2010. Control of Fusarium Wilt with Chitinolytic Bacteria. HAYATI J Bioscie 17:5-8.

Toju H, Tanabe AS, Yamamoto S, Sato H. 2012. HighCoverage ITS Primers for the DNA-Based Identification of Ascomycetes and Basidiomycetes in Environmental Samples. PLoS ONE 7 : 1 - 11.

Wongpia A, Lomthaisong K. 2010. Changes in the 2DE Protein Profiles of Chilli Pepper (Capsicum annuum) Leaves in Response to Fusarium oxysporum Infection. Science Asia 36 : 259 - 270. doi 10.2306/ scienceasia1513-1874.2010.36.259.

Zahara H, Harahap LH. 2007. Identifikasi jenis cendawan pada tanaman cabai (Capsicum annuum) pada topografi yang berbeda. Seminar Temu Teknis Pejabat Fungsional Non Peneliti. Bogor, 21 - 22 Agustus 2007. 